\title{
EVALUATION OF THE EFFECT OF SILDENAFIL IN HEMODIALYSIS PATIENTS WITH PULMONARY HYPERTENSION
}

\author{
Abdelrahman Ali Elbraky, Maha Abd El Moneim Behairy, Hazem Mohamed \\ Khorshid, Tamer Wahid Elsaid, Waleed Anwar AbdelMohsen and \\ Gamal EL Sayed Mady
}

\begin{abstract}
Department of Nephrology,
Faculty of Medicine, Ain

Shams University, Cairo, Egypt

Corresponding :

Abdelrahman Ali Elbraky

Mobile: 01003596257

E mail:

aelbraky@gmail.com,

Received: 14/7/2019

Accepted: 12/8/2019
\end{abstract}

\begin{abstract}
:
Background: Pulmonary hypertension $(\mathrm{PH})$ is one of the fatal and progressive conditions in ESRD patients, its prevalence among hemodialysis patients ranging from $19 \%$ to $70 \%$ and it is responsible for $50 \%$ of mortality rate.
\end{abstract}

Aim of the Work: To evaluate the effect of sildenafil on pulmonary artery pressure and six minute walk test (6MWT) in hemodialysis patients with pulmonary hypertension and detection of safety and optimum dose of the drug.

Patients and Methods: Prospective, Placebo Controlled, clinical trial involving 60 ESRD patients with pulmonary hypertension from January to May 2019.

Results: Group 1 (20 patients) received $25 \mathrm{mg}$ sildenafil, group 2 (20 patients) received $50 \mathrm{mg}$ sildenafil and group 3 (20 patients)who received placebo for 3 months .There was significant increase in mean of 6 MWT after treatment among group 1 and 2 but there is nonsignificant change among placebo group.

Estimated pulmonary artery pressure (e PAP) mean after treatment showed significant decrease among group 1,2 and 3.

In group 1 there was 4 patients with mild $P H, 13$ with moderate, 3 with severe $P H$ after treatment 5 patients downgraded from moderate to mild and 2 patients downgraded from severe to moderate .In group 2 there was 8 patients with mild PH, 6 patients with moderate and 4 patients with severe $\mathrm{PH}$ after treatment 4 patients downgraded from moderate to mild $\mathrm{PH}$ and 2 patients downgraded from severe to moderate PH. In group 3 only one patient downgraded from moderate to mild $\mathrm{PH}$.

Conclusion: Our clinical trial confirmed efficiency of 50mg and $25 \mathrm{mg}$ sildenafil on improving e PAP and functional exercise capacity in ESRD patients with $\mathrm{PH}$.

Key words: clinical trial, pulmonary hypertension, ESRD, sildenafil.

\section{INTRODUCTION:}

Pulmonary hypertension $(\mathrm{PH})$ is one of the fatal and progressive conditions in (ESRD) patients its prevalence in hemodialysis patients ranges from $19 \%$ to
$70 \%$. Sildenafil is a phosphodiesterase inhibitor widely used in treatment of $\mathrm{PH}$ .Despite the potential burden of pulmonary hypertension in hemodialysis patients, such agent like sildenafil has limited studies about optimum dose, safety and long term efficacy 
in ESRD patients on hemodialysis with pulmonary hypertension.

\section{AIM OF THE WORK}

To evaluate the effect of sildenafil on pulmonary artery pressure and (6MWT) in hemodialysis patients with pulmonary hypertension. Also detection of safety of sildenafil in hemodialysis patients and Finding out sildenafil's optimum dose for hemodialysis patients with pulmonary hypertension.

\section{PATIENTS AND METHODS:}

This study was conducted between January and May of 2019 on 60 hemodialysis patient in Ain Shams University Hospitals divided randomly into 3 groups: group 1 (20 patients) received 25 mg sildenafil for 3 months group 2 (20 patients) received $50 \mathrm{mg}$ sildenafil daily for 3 months and group 3 (20 patients) who received placebo for 3 months.

We excluded any patient on current treatment of pulmonary hypertension (prostacyclin analogues, endothelin receptor antagonists or phosphodiesterase inhibitors). We also excluded any patient with heart diseases (congestive heart failure, ischemic heart disease, congenital heart disease),Lung diseases (chronic obstructive pulmonary disease, pulmonary thromboemboli or tumor, interstitial lung diseases, sleep apnea, pulmonary fibrosis, Sarcoidosis), systemic diseases (scleroderma, systemic lupus erythematosus, portal hypertension), human immunodeficiency virus (HIV) infection .

All patients after written informed consent approved by the ethical committee have been included into our registry and subjected to the following:

Every patient in the study was subjected to full history taking and clinical examination with special attention to symptoms of pulmonary hypertension.

I. Transthoracic echocardiography Was done at the begging of the study and after three months in mid-week non-dialysis day, the patients was assessed regarding:

- Change in ePAP via Doppler echocardiography pulmonary artery pressure calculated using the modified Bernoulli equation: PAP =tricuspid systolic jet (TR) + (10-15) $\mathrm{mm} \mathrm{Hg}$ (estimated right atrial pressure: $15 \mathrm{~mm}$ $\mathrm{Hg}$ in dilated right atrium and 10 $\mathrm{mmHg}$ in normal or slightly enlarged right atrium). $\mathrm{PH}$ was defined as a systolic PAP $>35 \mathrm{mmHg}$

- Right ventricular examination: Assessment of right ventricular functions by TAPSE (Tricusped annulus plane systolic excursion), tricuspedregerge (TR), estimated PASP, RV end-diastolic basal diameter, .RA end-systolic area, ejection fraction and left ventricle mass index (LVMI)

II. Exercise capacity assessment by 6MWT: The test was performed along a long, flat, straight, enclosed corridor with a hard surface. The test (6MWT) was done for every patient at the begging of the study (6MWT 1) and after 3 month of receiving the medication (6MWT 2).

Management: Group 1 (20 patients) received $25 \mathrm{mg}$ sildenafil daily for 3 months group 2 (20 patients) received $50 \mathrm{mg}$ sildenafil daily for 3 months and group 3 (20 patients) who received placebo daily for 3 months .

Follow up including:

patients improved or deteriorated, compliance and appearance of any drug side effect.

The collected data was revised, coded, tabulated and introduced to a PC using 
Statistical package for Social Science (SPSS 25). Data was presented and suitable analysis was done according to the type of data obtained for each parameter.

\section{RESULTS:}

Basic demographic baseline data between the 3 study groups

\begin{tabular}{|l|c|c|c|c|}
\hline & $\begin{array}{c}\text { Group 1 }(\mathrm{n}=19) \\
(25 \mathrm{mg})\end{array}$ & $\begin{array}{c}\text { Group 2 }(\mathrm{n}=18) \\
(50 \mathrm{mg})\end{array}$ & $\begin{array}{c}\text { Group 3 (n=19) } \\
(\text { placebo) }\end{array}$ & p value \\
\hline Age (years) & $52.6 \pm 10.8$ & $45.5 \pm 12.1$ & $52.2 \pm 7.0$ & .07 \\
\hline Gender: & & & & \\
$\quad$ Male & $12(65 \%)$ & $9(50 \%)$ & $12(63 \%)$ & .59 \\
$\quad$ Female & $7(35 \%)$ & $9(50 \%)$ & $7(37 \%)$ & \\
\hline Vascular access: & $4(21 \%)$ & $5(28 \%)$ & $5(26 \%)$ & .84 \\
$\quad$ Cath & $15(79 \%)$ & $13(72 \%)$ & $14(74 \%)$ & \\
$\quad$ AVF & $4 \pm 4$ & $2 \pm 1$ & $2.5 \pm 3$ & .004 \\
\hline Duration of HD(years) & $29.4 \pm 4$ & $29.7 \pm 4.6$ & $30 \pm 4$ & .91 \\
\hline BMI & $89.3 \pm 14$ & $96.2 \pm 9.3$ & $96.4 \pm 11.2$ & .201 \\
\hline MBP (mmHg) & $82.4 \pm 15$ & $85.9 \pm 13$ & $85.7 \pm 11.7$ & .95 \\
\hline Dry WT(kg) & $75.8 \pm 6.6$ & $80 \pm 7$ & $78 \pm 6.1$ & .32 \\
\hline Pulse(b/min) & & & & \\
\hline
\end{tabular}

\section{Etiology of Renal faliure}

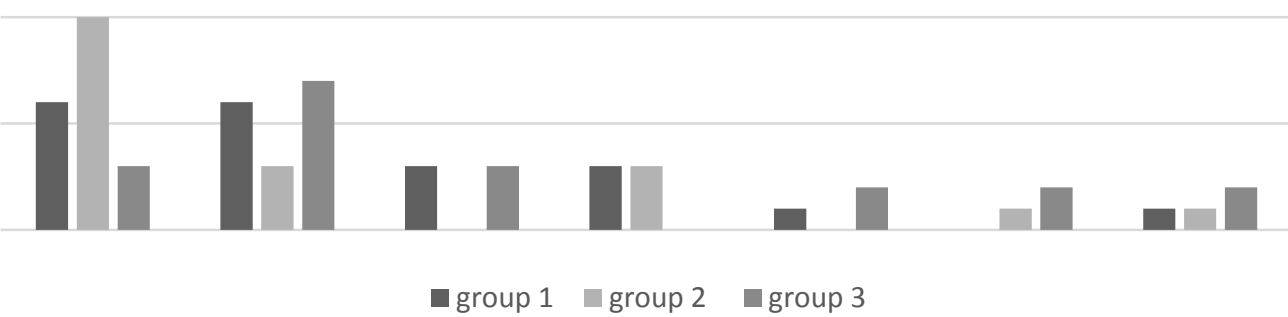

Table (3) Basic Echo cardiographic data among studied groups

\begin{tabular}{|l|c|c|c|c|}
\hline & $\begin{array}{c}\text { Group 1 } \\
25 \mathrm{mg}\end{array}$ & $\begin{array}{c}\text { Group 2 } \\
50 \mathrm{mg}\end{array}$ & $\begin{array}{c}\text { Group 3 } \\
\text { Placebo }\end{array}$ & p value \\
\hline EF & $55 \pm 8.6$ & $59 \pm 11$ & $58 \pm 5$ & $.26^{\#}$ \\
\hline LVMI & $93.8 \pm 12$ & $93.1 \pm 14$ & $92 \pm 11$ & $.75^{\#}$ \\
\hline RV ED BD & $34.7 \pm 3.5$ & $35.3 \pm 4.4$ & $35 \pm 3$ & $.88^{\#}$ \\
\hline RA ES area & $15.9 \pm 1.8$ & $16.3 \pm 1.9$ & $15.9 \pm 1.9$ & $.59^{\#}$ \\
\hline e PAP 1 & $49.4 \pm 7.7$ & $48.7 \pm 11.5$ & $47 \pm 8.1$ & $.8^{\#}$ \\
\hline TR : -ve & $10(50 \%)$ & $12(66 \%)$ & $11(58 \%)$ & $.89^{\# \#}$ \\
Mild & $7(35 \%)$ & $5(28 \%)$ & $7(37 \%)$ & \\
Moderate & $2(15 \%)$ & $1(6 \%)$ & $1(5 \%)$ & \\
Severe & $0(0 \%)$ & $0(0 \%)$ & $0(0 \%)$ & \\
\hline RVF : normal & $16(84 \%)$ & $14(78 \%)$ & $14(74 \%)$ & $.72^{\# \#}$ \\
impaired & $3(16 \%)$ & $4(22 \%)$ & $5(26 \%)$ & \\
\hline
\end{tabular}

There was no significantly statistical difference between the 3 groups regarding $\mathrm{EF}$, LVMI, right ventricular end diastolic basal diameter, right atrial end systolic area, ePAP, tricuspid regurge and right ventricular function. 
Abdelrahman Ali Elbraky, et al.,

Comparison between 6MWT pre and post intervention

\begin{tabular}{|c|c|c|c|c|}
\hline & $\begin{array}{c}\text { Group 1 } \\
25 \mathrm{mg}\end{array}$ & $\begin{array}{c}\text { Group 2 } \\
50 \mathrm{mg}\end{array}$ & $\begin{array}{c}\text { Group3 } \\
\text { Placebo }\end{array}$ & $\begin{array}{c}\mathrm{p} \\
\text { value }\end{array}$ \\
\hline 6 MWT 1 & $171 \pm 45$ & $214 \pm 58$ & $175 \pm 39$ & .06 \\
\hline Sig. bet. grps & \multicolumn{2}{|c|}{$\mathrm{p} 1=.24}$, & $\mathrm{p} 2=.93, \quad \mathrm{p} 3=.064$ & \\
\hline 6 MWT 2 & $205 \pm 57$ & $258 \pm 59$ & $182 \pm 49$ & .001 \\
\hline Sig. bet. grps & \multicolumn{2}{|c|}{$\mathrm{p} 1=.027, \quad \mathrm{p} 2=.45, \quad \mathrm{p} 3=.001$} & \\
\hline p value & .00 & .00 & .15 & \\
\cline { 1 - 3 }
\end{tabular}

$\mathrm{p} 1$ : $\mathrm{p}$ value for comparing group 1 and group $2 / \mathrm{p} 2$ : $\mathrm{p}$ value for comparing group 1 and group 3

p3: $\mathrm{p}$ value for comparing group 2 and group 3

Shows significant increase in mean of 6 MWT after treatment among group 1 and 2 but there is non- significant change among placebo group. There was no significant differences between the 3 groups regarding basal means of 6 MWT. A significantly statistical difference between three groups after treatment $(P<0.01)$ as post Hoc test results was statistically significant increase in 6MWT2 in group 2 in comparison to group 1 of $(P<0.05)$, there was also statistically high significant increase in 6MWT 2 in group $2(50 \mathrm{mg})$ in comparison to group 3 (placebo ) $(P<.001$.

Improvement in $6 \mathrm{MWT}$ in the 3 group post treatment

\begin{tabular}{|l|c|c|c|c|}
\hline & $\begin{array}{c}\text { Group 1 } \\
25 \mathrm{mg}\end{array}$ & $\begin{array}{c}\text { Group 2 } \\
50 \mathrm{mg}\end{array}$ & $\begin{array}{c}\text { Group 3 } \\
\text { Placebo }\end{array}$ & $\begin{array}{c}\text { P } \\
\text { value }\end{array}$ \\
\hline $\begin{array}{l}\text { Improvement on 6MWT } \\
\text { (Change } \geq 30 \text { meters ) }\end{array}$ & $\begin{array}{c}13 \\
(76 \%)\end{array}$ & $\begin{array}{c}12 \\
(75 \%)\end{array}$ & .001 \\
\hline No improvement in 6 MWT & $\begin{array}{c}(19 \%) \\
\end{array}$ & $\begin{array}{c}4 \\
(24 \%)\end{array}$ & $\begin{array}{c}13 \\
(25 \%)\end{array}$ & .001 \\
\hline
\end{tabular}

There was significant increase in versus group 3 with only (19\%) improvement on 6MWT post treatment in improvement in 6MWT.

both group $1(76 \%)$ and group $2(75 \%)$

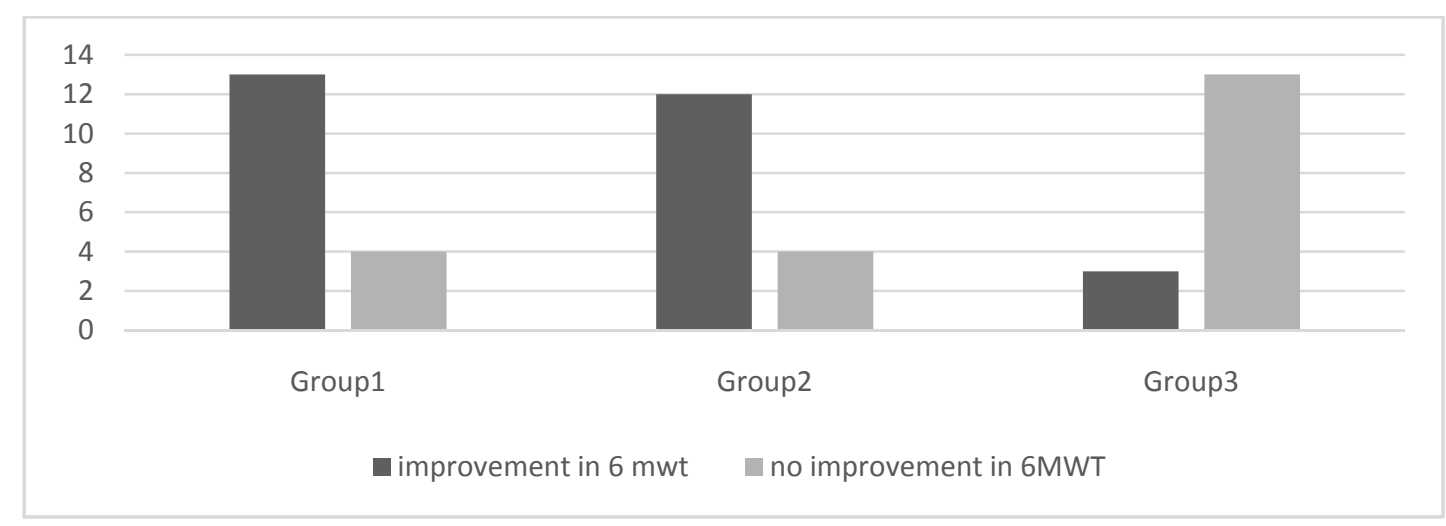


Comparison between e PAP pre and post intervention

\begin{tabular}{|c|c|c|c|c|}
\hline & $\begin{array}{c}\text { Group 1 } \\
25 \mathrm{mg}\end{array}$ & $\begin{array}{c}\text { Group 2 } \\
50 \mathrm{mg}\end{array}$ & $\begin{array}{c}\text { Group3 } \\
\text { Placebo }\end{array}$ & $\mathrm{p}$ value \\
\hline ePAP1 & $48 \pm 9$ & $43.5 \pm 16$ & $48.5 \pm 12$ & .804 \\
\hline Sig. bet. grps & \multicolumn{2}{|c|}{$\mathrm{p} 1=.98, \quad \mathrm{p} 2=.80, \quad \mathrm{p} 3=.88$} & \\
\hline ePAP2 & $42 \pm 9$ & $39 \pm 15$ & $44.5 \pm 8$ & .251 \\
\hline Sig. bet. grps & \multicolumn{2}{|c|}{$\mathrm{p} 1=.97, \quad \mathrm{p} 2=.28, \quad \mathrm{p} 3=.37$} & \\
\hline pvalue & .00 & .00 & .00 & \\
\cline { 1 - 2 } & &
\end{tabular}

$\mathrm{p} 1$ : $\mathrm{p}$ value for comparing group 1 and group $2 / \mathrm{p} 2: \mathrm{p}$ value for comparing group 1 and group 3

p3: $p$ value for comparing group 2 and group 3

e PAP mean change in each group after treatment with significant decrease among group 1, 2 and 3.There were no statistically significant difference between the 3 studied groups regarding e PAP1 before and e PAP2 after the intervention

Comparison between grading of severity of $\mathrm{PH}$ in the 3 study group pre and post treatment

\begin{tabular}{|c|c|c|c|c|c|c|}
\hline & \multicolumn{2}{|c|}{ Group1 } & \multicolumn{2}{c|}{ Group2 } & \multicolumn{2}{c|}{ Group3 } \\
\cline { 2 - 7 } & pre & Post & pre & post & pre & post \\
\hline Mild & 4 & 11 & 8 & 12 & 7 & 8 \\
ePAP=25-40 & $(20 \%)$ & $(53 \%)$ & $(45 \%)$ & $(67 \%)$ & $(37 \%)$ & $(42 \%)$ \\
\hline Moderate & 13 & 8 & 6 & 4 & 11 & 10 \\
ePAP 41-55 & $(65 \%)$ & $(42 \%)$ & $(33 \%)$ & $(22 \%)$ & $(58 \%)$ & $(53 \%)$ \\
\hline Severe & 3 & 1 & 4 & 2 & 1 & 1 \\
ePAP $>55$ & $(15 \%)$ & $(5 \%)$ & $(22 \%)$ & $(11 \%)$ & $(5 \%)$ & $(5 \%)$ \\
\hline
\end{tabular}

In group 1 there was 4 patients with mild $\mathrm{PH}, 13$ with moderate, 3 with severe $\mathrm{PH}$, after treatment 5 patients downgraded from moderate to mild and 2 patients downgraded from severe to moderate .In group 2 there was 8 patients with mild $\mathrm{PH}, 6$ patients with moderate and 4 patients with severe $\mathrm{PH}$, after treatment 4 patients downgraded from moderate to mild $\mathrm{PH}$ and 2 patients downgraded from severe to moderate PH. In group 3 only one patients downgraded from moderate to mild $\mathrm{PH}$.

There was correlation between e PAP and right ventricular end diastolic basal diameter $(\mathrm{r}=.60, \mathrm{p}<.001)$, right atrial end systolic area $(\mathrm{r}=.45, \mathrm{p}<.001)$ which both has positive correlation with increased e PAP in pulmonary hypertension.

6 MWT done in the start of the study show negative correlation with only age $(\mathrm{r}=-$ $.42, \mathrm{p}<.001)$ as patient with older age seems to score less in the $6 \mathrm{MWT}$.

\section{DISCUSSION:}

Despite the potential burden of pulmonary hypertension in hemodialysis patients( prevalence ranges from $19 \%$ to $70 \%)^{(1)}$, such agent like sildenafil has no studies about optimum dose, safety and long term efficacy in ESRD patients on hemodialysis with pulmonary hypertension. Through our reviewing of literature there was no prior study emphasizing and studying the drug and its effect on ESRD patients with $\mathrm{PH}$.

\section{Basic characteristics:}

A comparison of demographic data between the 3 study groups demonstrated no significantly statistical difference between the 3 groups regarding age, sex, vascular access, BMI, dry weight, MBP and pulse. The only statistical significant difference was in duration of HD which was longer in group 1 
All basic echocardiographical data showed no statistically significant difference between the 3 study groups regarding EF, LVMI, right ventricular end diastolic basal diameter, right atrial end systolic area, e PAP, tricuspid regurge and right ventricular function.

\section{Change in e PAP:}

There was significant decrease in e PAP in all groups after treatment. In group 1 ePAP after treatment recorded mean of $(42 \pm 9)$ with significant decrease in relation to ePAP before treatment $(p<.00)$. Group 2 after treatment ePAP mean was $(39 \pm 15)$ with $(p<.00)$. Group 3 ePAP post treatment mean was $(42 \pm 9)$ and $(p=01)$.

There was significant decrease in e PAP in all groups after treatment. In group 1 ePAP after treatment recorded mean of $(42 \pm 9)$ with significant decrease in relation to ePAP before treatment $(\mathrm{p}<.00)$. Group 2 after treatment ePAP mean was $(39 \pm 15)$ with $(\mathrm{p}<.00)$. Group 3 ePAP post treatment mean was $(42 \pm 9)$ and $(p=01)$.

In comparison to Galié et al., $(2005)^{(2)}$ in his placebo-controlled study, he assigned 278 patients with symptomatic pulmonary arterial hypertension with no renal impairment to placebo or sildenafil $(20,40$, or $80 \mathrm{mg}$ ) orally daily for 12 weeks. All sildenafil doses reduced the mean pulmonary-artery pressure $(\mathrm{P}=0.04, \mathrm{P}=0.01$, and $\mathrm{P}<0.001$, respectively) in relation to placebo .

Hemodynamic variables are related to survival in patients with pulmonary arterial hypertension $^{(3)}$. It has been suggested that there is possible reverse remodeling of pulmonary vascular changes with both prostanoids and endothelin-receptor antagonists, on the basis of their antiproli-ferative properties, and this may also explain the effects seen with sildenafil ${ }^{(4)}$.

Change in 6MWT( functional assessment of patients with pulmonary hypertension):

There was no statistically significant difference between 3 groups regarding the
6MWT done at the begging of the study between the 3 groups $p$ value was nonsignificant $(p=.06)$.

There was statistically significant increase in 6MWT done after treatment in group $1 \quad(p<.001)$. Group 2 also had significant increase with mean of $(p<.001)$. However group 3 (placebo) shows no statistically significant difference $(p=.15)$.

We compared the effect of different doses of sildenafil on 6MWT, we reported that group 2 (receiving $50 \mathrm{mg}$ sildenafil) showed significant increase in (6MWT) in comparison to group 1 (receiving $25 \mathrm{mg}$ sildenafil $)(p<0.05)$ and highly significant increase in comparison to group 3 (receiving placebo $)(p<.001)$.

Our results agreed with Galié et al., (2005) who found that the distance walked in six minutes (6MWT) increased from baseline in all sildenafil groups for 20, 40, and $80 \mathrm{mg}$ of sildenafil, respectively $(P<0.001)$ in comparison to placebo. ${ }^{(2)}$

The six-minute walking test is an independent predictor of death in patients with pulmonary arterial hypertension and has been used as the primary end point in most clinical trials involving patients with pulmonary arterial hypertension. ${ }^{(5)}$

We observed in the our study positive correlation between e PAP and right ventricular end diastolic basal diameter $(r=.60)(p<.001)$ in our study group in agreement with Seo and Lee, (2018) study who observed that the RV dilates in response to increased PAP and that enlarged $\mathrm{RV}$ can predict mortality in patients with pulmonary disease and pulmonary arterial hypertension (PAH) ${ }^{(6)}$

There was also positive correlation between e PAP and right atrial end systolic area $(r=.45)(p<.001)$ in study group. That was consistent with a study conducted by Querejetaet al., (2015) who stated that patients with $\mathrm{PH}$ also had significantly larger 
RA area compared with controls $(15.0 \pm 4.7$ $\mathrm{cm}^{2}$ versus $\left.8.5 \pm 1.4 \mathrm{~cm}^{2}, P<0.001\right)^{(7)}$.

Although in our study group 2 (receiving 50mg sildenafil) showed better results and increase patient's functional exercise capacity there were 2 drop out through study due to drug related side effects the first one suffered from persistent hypotension after one weak from using medication and the second drop out from this group suffered from persistent headache after one month of treatment.

Side effects of sildenafil were reported to be nausea, hypotension, headache, palpitation, flushing, and angina in a study conducted on a Fifty-five hemodialysis patients above 18 years suffering from erectile dysfunction, A Single 50-mg sildenafil tablet was prescribed for each patient $^{(8)}$.

Group 1 (receiving $25 \mathrm{mg}$ sildenafil) showed statistically significant improvement in ePAP and 6MWT without any side effects in any patient in this group.

Conclusion: Our clinical trial confirmed efficiency of $50 \mathrm{mg}$ and $25 \mathrm{mg}$ sildenafil on improving e PAP and functional exercise capacity in ESRD patients with pulmonary hypertension. Although dose of $50 \mathrm{mg}$ daily is more effective in both decreasing ePAP and increasing functional exercise capacity (measured by 6MWT) dose of $25 \mathrm{mg}$ daily showed no side effect in such patients.

Limitations: Relatively small number of patients and it was a single center study

\section{REFERENCES}

1. Xu Q, Xiong L, Fan L, et al.: Association of pulmonary hypertension with mortality in incident peritoneal dialysis patients. Perit Dial Int 2014 Sep 2. pii: pdi.2013.00332

2. Galié N, Ghofrani H, Torbicki A, et al.: Sildenafil Use in Pulmonary Arterial Hypertension (SUPER) Study Group. Sildenafil citrate therapy for pulmonary arterial hypertension. The New England journal of medicine. (2005). 353. 2148-57. 10.1056/NEJMoa050010.

3. D'Alonzo GE, Barst RJ, Ayres SM, et al.: Survival in patients with primary pulmonary hypertension: results from a national prospective registry. Ann Intern Med 1991; 115: 343-349.

4. Tantini B, Manes A, Fiumana E, et al.: Antiproliferative effect of sildenafil on human pulmonary artery smooth muscle cells. Basic Res Cardiol 2005;100:131-138

5. Okumus G, Aslan GK, Arseven O, et al.: The role of an activity monitor in the objective evaluation of patients with pulmonary hypertension. Clin Respir J. 2018; Volume12, Issue1:119-125.

6. Seo HS and Lee H.: Assessment of right ventricular function in pulmonary hypertension with multimodality imaging. J Cardiovasc imaging. 2018;26(4):189-200.

7. Querejeta Roca G, Campbell P, Claggett B, et al.: Right atrial function in pulmonary arterial hypertension. Circ Cardiovasc Imaging 2015;8:e003521.

8. Sahin Y, Aygün C, Peşkircioğlu CL, et al.: Efficacy and safety of sildenafil citrate in hemodialysis patients.Transplant Proc. 2004 Jan-Feb; 36(1):56-8. 
تاثير عقار السيلانافيل على ارتفاع ضغط الدم في الشريان الرئوي في مرضى الاستصفاء الدموي عبدالرحمن علي البريقي , مها عبدالمنعم بحيري , حازم محمد خورشيد , تامر وحيد السعيد

وليد انور عبدالمحسن , جمال السيد ماضي

قسم الباطنة ـ كلية الطب -جامعة عين شمس

الخلفية: يعد مرض ارتفاع ضغط الثريان الرئوي من اخطر الامر اض في مرضى الفشل الكلوي المزمن و اكثر ها

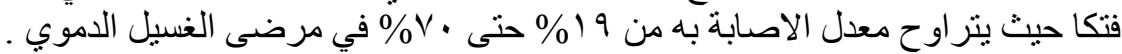

الهدف : تقييم تاثير عقار السيلدنافيل على ضغط الدم بالثريان الرئوي و التحسن الاكلينيكي في مرضى الغئي الغسيل

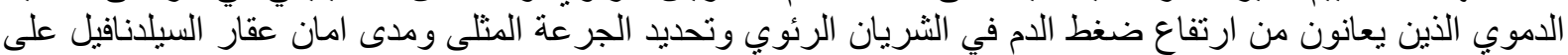

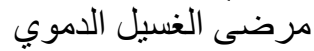

المرضي والطرق: كانت هذه تجربة سريرية على • ج من مرضى الغسيل الدموي المصابين بارتفاع ضغط الثريان

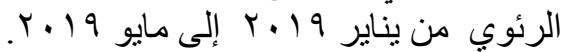

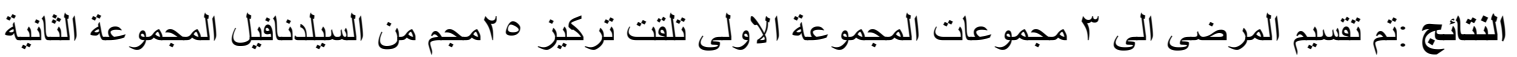

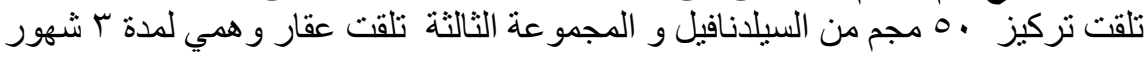
تم رصد تحسن ملحوظ في منوسط اختبار المشي لست دقائق في المجموعة الاولى و الثنانية في اخر الدراسة ولم يلاحظ اي تحسن في المجموعة الثنالثة .

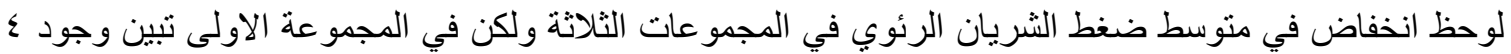

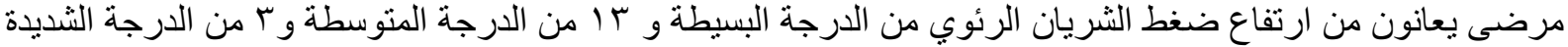

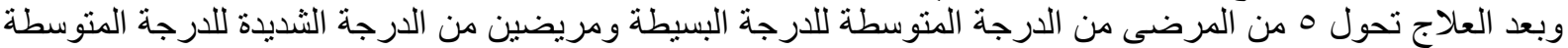

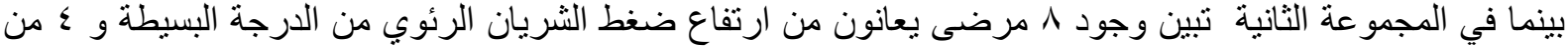

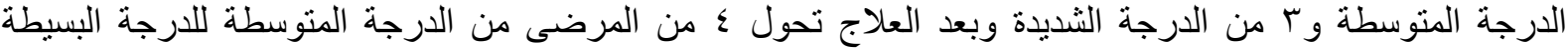

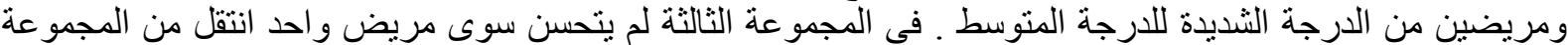
المتوسطة للبسيطة التربن

خاتمة: أكدت تجربتنا السريرية فعالية عقار السيلدنافيل بجرعتيه مب مجم و و .0 مجم في تحسين ضغط الثريان

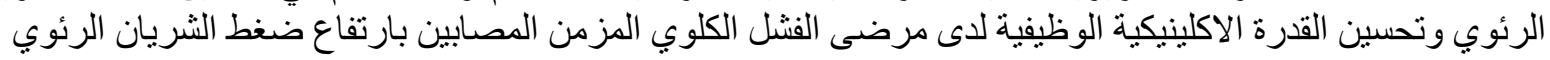

